\title{
教育講演
}

\section{8. 糖尿病治療の進歩}

\author{
加来 浩平
}

Key words：経口血糖降下薬，インスリン，早期介入，良質なHbA1c，患者中心の管理目標

\section{はじめに}

近年, 糖尿病患者は増加の一途をたどってい る. 厚生労働省による平成 23 年度国民健康・栄 養調査報告では, 我が国においてHbA1c 6.5\% 以 上の糖尿病が強く疑われるものが 950 万人と直 近の 5 年間で 60 万人増加している. 有病率は特 に中高年以降で高まり, 60 歳以降では $15 \%$ を超 えている. 一方で, 患者の治療状況をみると, 全体で $37 \%$ が受診しておらず, 治療を放置して いる．特に，いわゆる就労年齢に相当する 30 歳代から 50 歳代までの患者の受診率が極めて低 いことは懸念すべき点である，治療目標は，健 常人と変わらない日常生活の質 (QOL) と寿命 の確保である。そのためには合併症の発症, 進 展の防止が極めて重要となる. 合併症の抑制に 血糖管理が大きな役割を担うことは言うまでも ないが, 血圧, 脂質, 体重の管理も加えた統合 的な管理が有力な手段となる. 我が国の糖尿病 患者の寿命は, 非糖尿病者に比し, 男性で約 10 年, 女性で 13 年短いとの報告 ${ }^{1)}$ もり, 糖尿病
の克服が日本人の寿命の延長につながるものと 思われる。

日本人糖尿病患者の $90 \%$ 以上を占める 2 型糖 尿病の治療では，まず食事療法や運動療法など の生活習慣の改善を行い, 不十分な場合には薬 物療法を導入する。しかし, 多くの場合, 薬物 療法が必須となるのが現状である。近年, 新た な作用機序を持つ薬剂が次々と登場し, 多様性 に富む 2 型糖尿病の病態に対応した治療が可能 となりつつある.

\section{2 型糖尿病の病態と薬物療法の意義}

インスリン分泌不全とインスリン抵抗性は 2 型糖尿病の主たる病態であり，発症前(境界型) から存在し, 徐々に進行する ${ }^{2)}$. 病態進展過程か らみれば，進行性の疾患と捉えるべきであり， とりわけ膵 $\beta$ 細胞機能不全は経年的に低下し, $\beta$ 細胞量の減少を伴う ${ }^{3}$. 膵 $\beta$ 細胞量の減少には遺 伝的背景とともに, 糖毒性あるいは糖・脂肪毒 性が関与する。ささらに，インクレチン作用の減 弱も重要な役割を担う ${ }^{4)}$. より早期からの抗糖尿

川崎医科大学総合内科学 1

111th Scientific Meeting of the Japanese Society of Internal Medicine : Educational Lecture : 8. Progress in treatment of diabetes.

Kohei Kaku : Department of General Internal Medicine 1, Kawasaki Medical School, Japan.

本講演は, 平成 26 年 4 月 12 日（土）東京都・東京国際フォーラムにて行われた. 


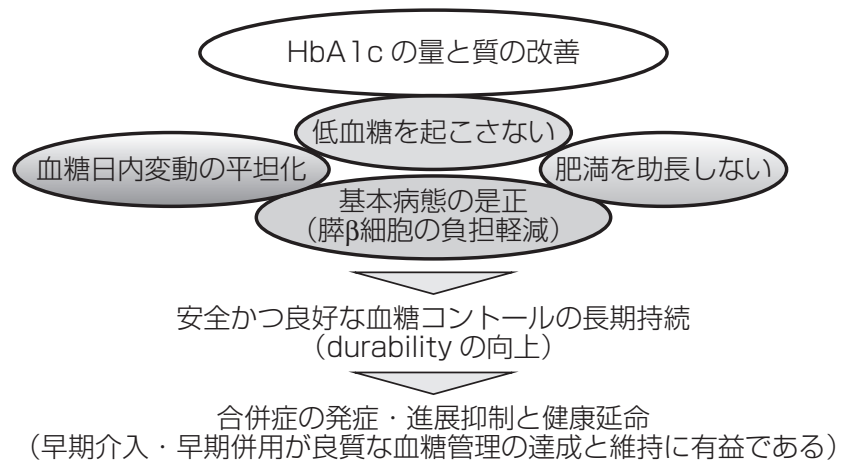

図 1. 合併症阻止と病態進展阻止のための良質な血糖管理

病薬による積極的介入は, 病態進展阻止による 良好な血糖管理の維持の面から極めて大きな意 義を持つ. DCCT/EDIC (Diabetes Control and Complications Trial/Epidemiology of Diabetes Interventions and Complications), UKPDS (United Kingdom Prospective Diabetes Study), UKPDS80, STENO-2 スタディなど, 大規模前向 き臨床研究の成果は, より早期からの薬剤介入 による積極的な血糖管理が総死亡や血管合併症 の抑制に寄与することを明らかにし, metabolic memory（あるいはglucose memory）, legacy effectという言葉が定着している5 ${ }^{5,6}$. より厳格な 血糖管理とともに治療目標達成には血糖コント ロールの長期持続 (durability)が求められるが, 早期介入による経年的な病態進展は, durability 向上のためにも重要である。また血管合併症阻 止の観点からは, $\mathrm{HbAlc} の$ 量的改善のみならず, 低血糖リスク減少や日内変動幅の縮小を伴う, いわゆる質的な改善も薬物療法に求められる重 要なポイントである（図1).

\section{2. 薬物療法の適応と治療薬の選択}

2 型糖尿病の薬物療法には, 経口血糖降下薬 (経口薬) と非経口薬（インスリンとGLP-1 受容 体作動薬）があり, 病態によって使い分けられ る. 高血糖患者を診る場合, まずはインスリン 治療の適応の是非を考慮する必要がある. 絶対
的適応はケトーシス傾向のある明らかなインス リン依存状態, 妊娠糖尿病で薬物療法が必要な 場合などである。 また，インスリン非依存状態 であっても, 随時血糖が $300 \mathrm{mg} / \mathrm{dl}$ 以上の高血糖 状態や重症感染症, 全身管理が必要な外科手術 時などの場合はインスリン治療の適応となる. 経口薬はインスリン非依存状態で, 食事療法お よび運動療法を十分に行っても血糖值が目標に 達しない場合に適応となる.

インスリンを含む薬物療法によって, 血糖正 常化を目指したACCORD (Action to Control Cardiovascular Risk in Diabetes) PVADT (Veterans Affairs Diabetes Trial) スタディなどでは, 重症低血糖の発現はむしろ心血管死による死亡 リスクを高めていた ${ }^{7,8)}$. それらの結果を受けて, 欧米では患者中心の管理目標設定（patientcentered approach）の重要性と, 安全な血糖コ ントロールの重要性を示すとともに, 新たな薬

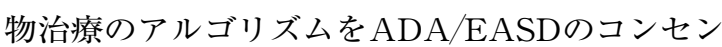
サスガイドラインとして提唱した9). すなわち, 薬剂の選択は, 個々の薬物の作用の特性や副作 用を考慮に入れながら, 個々の患者の病態に応 じて行う。欧米では 2 型糖尿病の診断と同時ま たは診断後早期にメトホルミンを開始すること を推奨しているが, 2 型糖尿病の病態やライフス タイルが異なる我が国では実情に合致しないた め, 病態に応じた最適な薬剤選択を推奨してい る. 


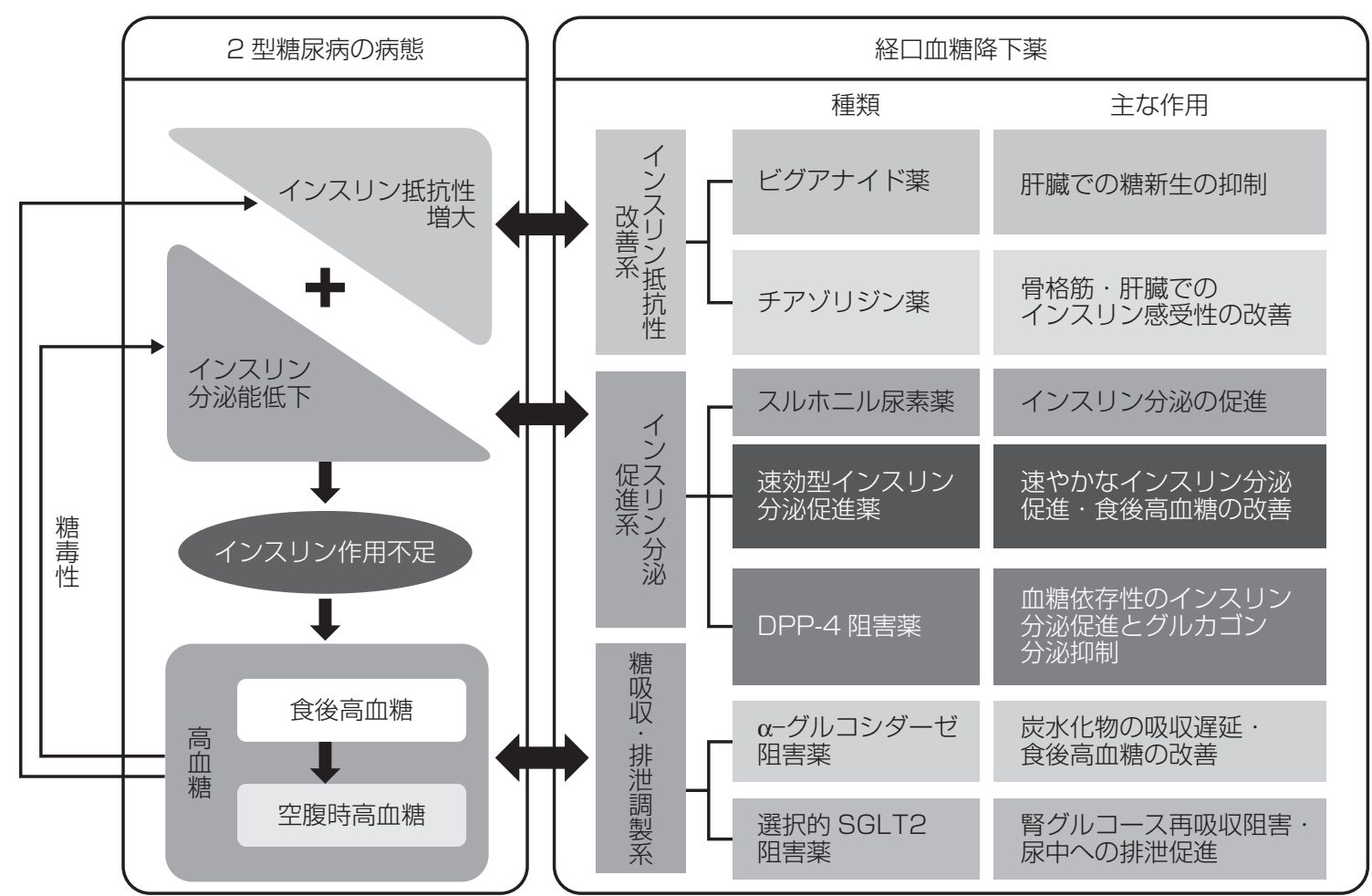

文献 10 より引用

図 2. 病茎に合わせた経口血糖降下薬の選択

\section{3. 各種経口血糖降下薬の特徵}

本邦では作用機序の異なる 7 種類の経口薬が 使用可能であり，諸外国に比べて豊富である. 作用別にインスリン分泌促進系，インスリン抵 抗性改善系, 糖質吸収・排泄調節系に分けられ る (図 2) ${ }^{10)}$.

\section{1）インスリン分泌促進薬}

SU薬, グリニド薬, DPP-4 阻害薬が該当する. SU薬は古くから汎用されてきたが, 現在はいわ ゆる第三世代と称されるグリメピリドの使用頻 度が高い。高用量での長期使用は低血糖や体重 増加などを来たしやすいことから, 中等量以下 での使用が薦められる。グリニド薬は, 速効・ 短時間型インスリン分泌促進薬であり，食後高 血糖の是正を目的に, 1 日 3 回 (毎食直前) の内
服が必要となる. DPP4 阻害薬は, インクレチン （GLP-1 およびGIP）の血中濃度を維持すること で血糖降下作用を発揮する。インクレチンは血 糖依存的にインスリン分泌を促進し，グルカゴ ン分泌を抑制するため, 単独使用では低血糖を 起こしにくく，また体重増加を認めない.

\section{2）インスリン抵抗性改善薬}

(1) ビグアナイド薬

肝臓での糖新生を抑制することが主な作用で あるが, 近年, メトホルミンの作用機構の解明 が進んでいる．すなわち，AMPK活性化ととも にグルカゴン受容体シグナルの抑制効果が明ら かにされた ${ }^{11)}$. 臨床的には肥満・非肥満にかかわ らず血糖改善を認める点や, 消化器症状は軽度 認めるものの, 低血糖を起こさず体重増加を認 めない点も利点であり, 日本人 2 型糖尿病の第 一選択薬としても有用であると考える．重篤な 
合併症としての乳酸アシドーシスがあるが, 腎 機能障害や造影検査時等に留意して使用すれば 発症しにくいとされている。しかし, 使用頻度 の増大とともに, 乳酸アシドーシスの報告例が 増えており, 特に高度の腎機能障害者や脱水を きたしやすい高齢者などでの使用には留意すべ きである。

（2）チアゾリジン薬

主にアデイポカイン調節作用を介して作用を 発揮する．単独では低血糖を起こしにくいが, 副作用としてNa再吸収増加による浮腫や体重増 加, 閉経後女性の骨粗鬆症リスクなどが挙げら れる. 膀胱癌リスクについては十分な根拠はな く,さらなる検証が必要と思われる。一方で, 抗動脈硬化作用や脂質改善作用等を有しており, 大血管イベント（特に心血管イベント）の抑制 が示唆されている ${ }^{12}$. さらにインスリン導入を遅 らせるとの報告もされている12,13).

\section{3）糖質吸収・排泄調節系薬}

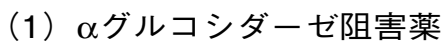

腸管でのブドウ糖への分解を阻害し, 糖の吸 収を遅らせることにより食後の高血糖を抑制す る薬剂である. 血糖降下作用は若干劣るものの, 単独では低血糖を起こしにくく, 体重増加を来 たさないのが利点である。 また, 境界型糖尿病 （impaired glucose tolerance：IGT）患者への投 与により, 糖尿病の発症進展を抑制し, また心 血管イベントの抑制効果も示めされており, IGT の段階から薬殽早期介入の必要性が示されてい $る^{14,15)}$. 副作用としては, 腹部膨満や下痢等の消 化器症状があるが, 内服継続中に自然経過で軽 快するものが少なくない. 欧米での使用頻度は 極めて低く，主に我が国を含むアジア諸国で使 用されている.

(2) SGLT2 阻害薬

$\mathrm{Na}$ グルコース共役輸送体（sodium glucose transporter：SGLT)の中でも特に腎尿細管に特 異的に発現するSGLT2 活性を阻害し, 過剩なグ ルコースを尿中に排泄させることで血糖低下に
働く.すなわちインスリン作用から独立した作 用機構を持つ新規血糖降下薬である. SGLT2 阻害に伴って, SGLT1 のグルコース再吸収能の 増大や速やかな肝蔵での糖新生立進がみられる ことが明らかにされている16,17). したがって, 単 独使用の場合は低血糖のリスクは低い. 既存薬 と異なる作用機序を有するため, どの既存薬と 併用しても優れた血糖改善効果が期待される.

HbAlc低下効果は, ベースライン值によって異 なるが, HbAlc $8 \%$ 程度であれば $1 \%$ 弱の低下 が期待できる. その際に空腹時血糖 20〜 30 mg/ $\mathrm{dl}$, 食後 2 時間值を $50 \mathrm{mg} / \mathrm{dl}$ 程度低下させる. SGLT2 阻害薬投与によって, 1 日 70〜90 gの尿 糖 (約 $300 \mathrm{kcal}$ に相当) 排泄によるエネルギーロ スが体重減少をもたらし, 肥満者では主に内臓 脂肪の減少を反映する. さらに浸透圧利尿と体 重減少によって血圧低下 (収縮期 4 $5 \mathrm{mmHg}$, 拡張期 2 $3 \mathrm{mmHg}$ ) も期待できる.さらに, 臨 床試験から糖毒性の改善に伴うインスリン抵抗 性やインスリン分泌能の改善も示唆されており, SGLT2 阻害薬は全身の代謝状態を改善し, 糖尿 病の進展と合併症の発症をも予防できる可能性 を秘めている (図 3) ${ }^{18)}$. 一方, 薬効薬理上, 糸 球体機能が一定以上低下した症例では有効性は 期待できず, $30 \leq \mathrm{eGFR}<60 \mathrm{ml} /$ 分 $/ 1.73 \mathrm{~m}^{2}$ は慎 重投与, eGFR $<30 \mathrm{ml} /$ 分 $/ 1.73 \mathrm{~m}^{2}$ および透析中 の末期腎不全患者は禁忌となる。また, 尿糖増 加による尿路・性器感染症リスク, SU薬やイン スリンとの併用時の低血糖発現リスクは本邦の 臨床試験でも認められている ${ }^{19)}$.さらに臨床試験 では明らかではないものの, 作用機構から脱水 を引き金とした心血管障害リスクや内因性イン スリン分泌の著明低下者でのケトアシドーシス のリスクは, 実臨床では十分に留意すべき点で ある.また, 非肥満者における除脂肪体重低下 (筋肉量の減少) は特に高齢者でのサルコペニア のリスク増大につながりかねない.

2014 年 6 月の時点ですでに 4 製剤が, 年内に 6 製剤全てが薬価収載の予定である. 規制当局は 


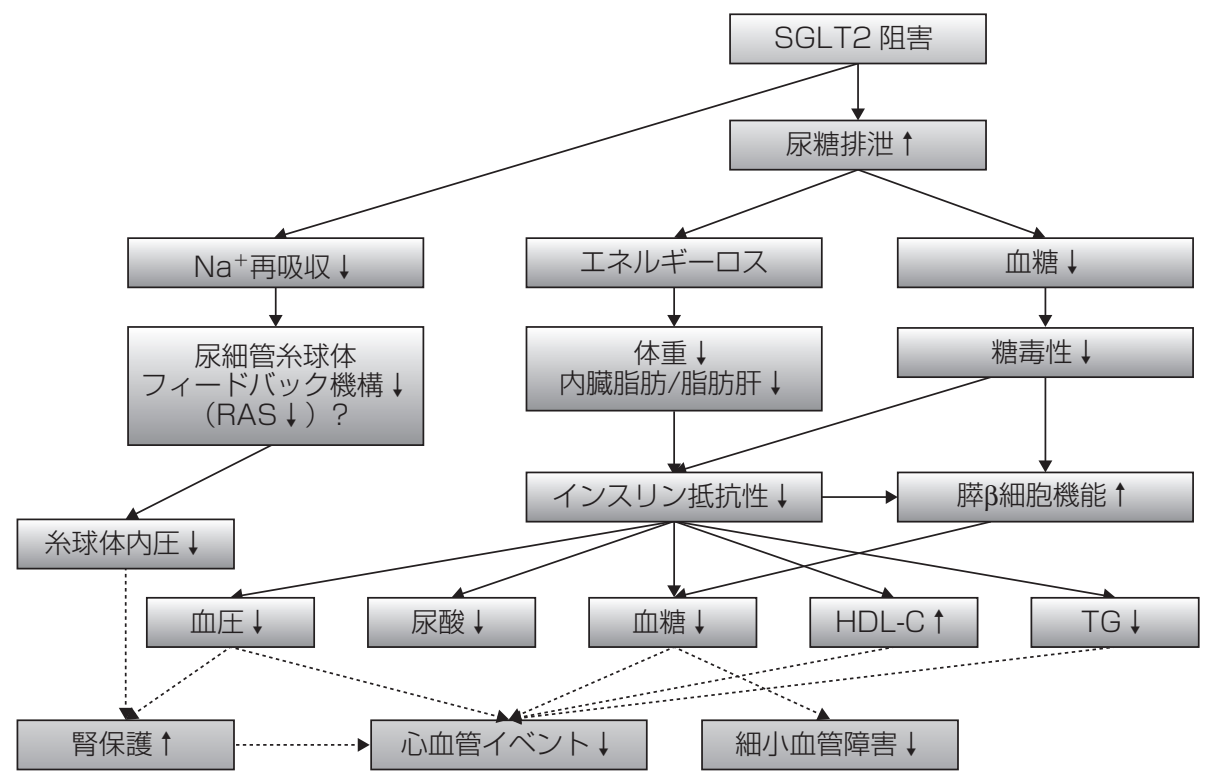

文献 18 より一部改変

図 3. SGLT2 阻害薬の代謝改善作用（概念図）

全ての製剂に対して, 発売 3 カ月以内に使用し た 65 歳以上の症例を対象とした 1 年間の特別使 用成績調査を依頼しており，高齢者での安全性 の担保を求めている.

\section{4. 薬物療法の実際}

インスリン非依存状態の 2 型糖尿病の場合, 高血糖の程度，インスリン分泌状態やインスリ ン抵抗性の状態, 合併症等の状態を考慮して薬 剂選択を行う (図 4) ${ }^{20)}$. 一般には, 経口薬の単 独療法から開始し, 不十分であれば経口薬併用, さらには経口薬に基礎インスリン補充を併用す るBOT (basal-supported oral therapy), 追加イ ンスリン補充（Basal-Bolus療法）と, 段階的な 治療のレベルアップが行われることが多い. し かし，段階的アプローチでは，長期的には良好 な血糖コントロールの維持は困難な場合が多い のも事実であり, 早期からの併用療法の導入は 十分に考慮されるべきである. 2 型糖尿病の病態 は多様性に富むことから，作用機序が異なる経
口薬の併用は理にかなったものであり，本邦に おいても数種類の配合薬が使用可能となってい る.

血糖コントロールの管理指標として，まず HbAlc 7\% 未満の達成を目指し, 低血糖などが なく, 安全に行えるのであれば, HbAlc 6\% 未 満の血糖正常化を目指す。治療強化が困難な場 合でも HbAlc 8\% 未満を達成する ${ }^{21)}$.これはあく まで一般的な目安であり，実際の管理目標は患 者の年齢, 合併症の有無などを考慮し, 患者ご とに設定することが重要である.

以下に薬物療法の具体的な考え方を示す.

1) $\mathrm{HbA} 1 \mathrm{c}$ が $8 \%$ 以上の場合

食事・運動療法に加え, 各種経口薬の併用中 であれば, 内因性インスリン分泌能を確認する. インスリン依存期に近いと判断すれば，インス リン治療を考慮すべきである，経口薬未治療例 では, 食事・運動療法に加えて経口薬治療で対 応できる場合が多いが, 病歴が長い例あるいは 経口薬単剂で血糖改善が認められない場合には, 速やかな併用療法あるいはインスリン導入を考 


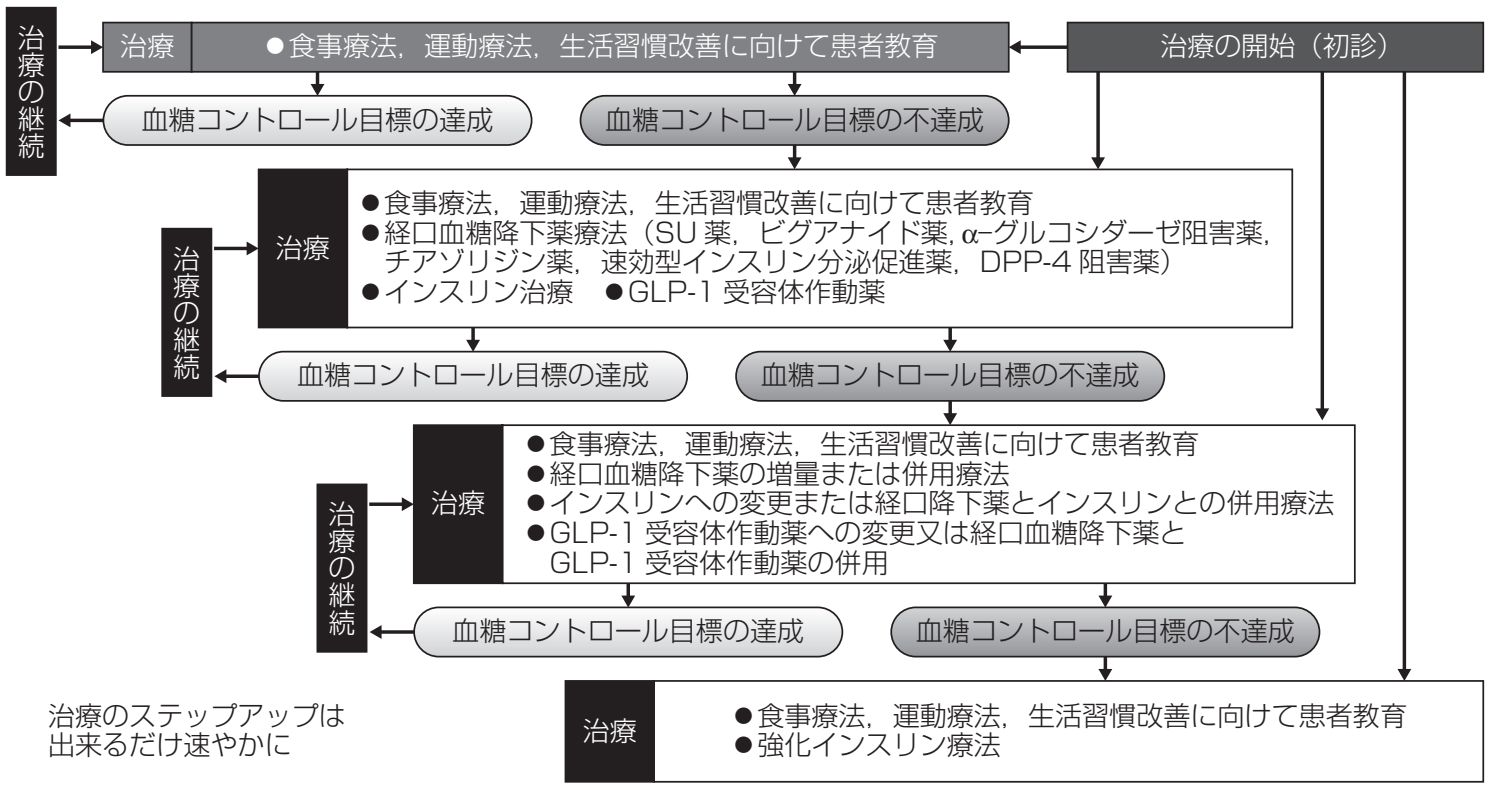

文献 20 上り一部改変

図 4. 糖尿病治療の進め方（インスリン非依存状態）

慮する.

2） $\mathrm{HbA} 1 \mathrm{c}$ が 7〜8\% 以上の場合

まずは食事療法, 運動療法を行い, 改善がな い場合, 経口薬を開始する. 肥満例, とりわけ 内臓肥満を合併する例では, ビグアナイド薬や DPP-4 阻害薬などから開始する場合が多い. 理 想体重以下の場合, インスリン分泌が低下して いる場合が多く,グリニド薬や少量のSU薬など から開始することもある。 また, 非高齢で肥満 がある場合は, SGLT2 阻害薬も適応になりうる が，あくまで十分な食事・運動療法のもとでの 使用が求められる. 多くの場合, 併用療法が行 われるが, 血糖が改善した時点で再度病態を見 直し，治療方針を立て直すことも重要である.

\section{3） $\mathrm{HbA} 1 \mathrm{c}$ が $7 \%$ 未満の場合}

食後高血糖が主体である場合が多い. 食事療 法, 運動療法にて改善のない場合は食後高血糖 是正目的で $\alpha$ グルコジーゼ阻害薬, DPP-4 阻害 薬, グリニド薬などが第一選択になりやすい.
肥満があり，インスリン抵抗性を呈している場 合は, ビグアナイド薬やチアゾリジン薬などか ら開始，または併用することも有効である。

おわりに

一般に薬物療法は長期にわたる.したがって, 長期安全性の担保は何よりも重要であり, 薬物 療法の適応を考える際には, 常にリスク（安全 性）とベネフィット (有効性) のバランスを考 慮すべきである，低血糖や肥満（リスク）を少 なくし，管理目標を達成（ベネフィト）するに は, 患者ごとの血糖管理目標の設定と良質な血 糖コントロールの達成が必須である. 一方, 近 年の糖尿病患者の肥満度は上昇している.これ からの糖尿病対策には, 従来の血管合併症に加 えて, 過栄養や肥満との関連性が注目される認 知症, 癌, 骨関節症候群の抑制も念頭に置いた, トータルの糖尿病管理と肥満管理が求められる 


\section{ことを強調しておきたい.}

著者のCOI（conflicts of interest）開示：加来浩平；報酬 (武田薬品工業, ノボノルディスクファーマ), 講演料 (興和 創薬, 大日本住友製薬, 武田薬品工業, 田辺三菱製薬, ノボ ノルディスクファーマ), 寄付金 (MSD, 第一三共, 大正製 薬, 武田薬品工業, 中外製薬, ノボノルディスクファーマ)

\section{文献}

1）堀田 饒, 他：アンケート調査による日本人糖尿病の死 因一1991 2000 年の 10 年間, 18,385 名での検討一. 糖 尿病 $50: 47-61,2007$.

2) Kendall DM, et al : Clinical application of incretin-based therapy:therapeutic potential, patient selection and clinical use. Am J Med 122 : S37-S50, 2009.

3) Butler AE, et al : Beta-cell deficit and increased beta-cell apoptosis in humans with type 2 diabetes. Diabetes 52 : 102-110, 2003

4) Nauck MA, et al : Reduced incretin effect in Type 2 (non insulin-dependent) diabetes. Diabetlogia 29 : 46-52, 1986.

5) The DCCT/EDIC Study Research Group : Intensive diabetes treatment and cardiovascular disease in patients with type 1 diabetes. N Engl J Med 353 :2643-2653, 2005.

6) Holman RR, et al : 10-years follow-up of intensive glucose control in type 2 diabetes. N Engl J Med 359 : 1577-1589, 2008.

7) Action to Control Cardiovascular Risk in Diabetes Study Group : Effects of intensive glucose lowering in type 2 diabetes. N Engl J Med 358 : 2545-2559, 2008.

8) Duckworth W, et al : Glucose control and vascular complications in veterans with type 2 diabetes. $\mathrm{N}$ Engl J Med 360 : 129-139, 2009.

9) Inzucchi SE, et al : Management of hyperglycemia in type 2 diabetes : a patient-centered approach. Diabetes Care 35 : 1364-1379, 2012.

10）日本糖尿病学会編：糖尿病治療ガイド 2014-2015. 文光 堂, 2014, 29.
11) Miller RA, et al : Biguanides suppress hepatic glucagon signalling by decreasing production of cyclic AMP. Nature $494: 256-260,2013$.

12) Dormnady J, et al : Secondary prevention of macrovascular events in patients with type 2 diabetes in the PROactive Study : a randomized controlled trial. Lancet 366 : 1279-1289, 2005.

13) Kaku K, et al : Long-term effects of pioglitazone in Japanese patients with type 2 diabetes without a recent history of macrovascular morbidity. Curr Med Res Opin 25: 2925-2932, 2009.

14) Chiasson JL, et al: Acarbose for prevention of type 2 diabetes mellitus : the STOP-NIDDM randomized trial. Lancet 359 : 2072-2077, 2002.

15) Kawamori R, et al: Voglibose for prevention of type 2 diabetes mellitus : a randomized, double-blind trial in Japanese individuals with impaired glucose tolerance. Lancet 373 : 1607-1614, 2009.

16) Ferrannini E, et al:Metabolic response to sodiumglucose cotransporter 2 inhibition in type 2 diabetic patients. J Clin Invest 124 : 499-508, 2014.

17) Merovci A, et al : Dapagliflozin improves muscle insulin sensitivity but enhances endogenous glucose production. J Clin Invest $124: 509-514,2014$.

18）加来浩平：新たな作用機序による経口血糖降下薬《選択 的SGLT2 阻害薬》の有効性と安全性. 診療と新薬 50 : 607-614, 2013.

19) Kaku K, et al : Efficacy and safety of monotherapy with the novel sodium/glucose cotransporter-2 inhibitor tofogliflozin in Japanese patients with type 2 diabetes mellitus : a combined Phase 2 and 3 randomized, placebocontrolled, double-blind, parallel-group comparative study. Cardiovasc Diabetol 13:65, 2014. doi:10.1186/14752840-13-65

20）日本糖尿病学会編 : 糖尿病治療ガイド 2014-2015. 文光 堂, 2014, 28.

21）日本糖尿病学会編 : 糖尿病治療ガイド 2014-2015. 文光 堂, 2014, 25. 